\title{
A Critical Role for Protein Degradation in the Nucleus Accumbens Core in Cocaine Reward Memory
}

\author{
Zhen-Yu Ren ${ }^{1,2,3}$, Meng-Meng Liu, ${ }^{2,3}$, Yan-Xue Xue ${ }^{2,3}$, Zeng-Bo Ding ${ }^{2}$, Li-Fen Xue ${ }^{2}$, Suo-Di Zhai' and Lin Lu',2 \\ 'Pharmacy Department, Peking University Third Hospital, Beijing, China; ${ }^{2}$ National Institute on Drug Dependence, Peking University, Beijing, \\ China
}

\begin{abstract}
The intense associative memories that develop between cocaine-paired contexts and rewarding stimuli contribute to cocaine seeking and relapse. Previous studies have shown impairment in cocaine reward memories by manipulating a labile state induced by memory retrieval, but the mechanisms that underlie the destabilization of cocaine reward memory are unknown. In this study, using a Pavlovian cocaineinduced conditioned place preference (CPP) procedure in rats, we tested the contribution of ubiquitin-proteasome system-dependent protein degradation in destabilization of cocaine reward memory. First, we found that polyubiquitinated protein expression levels and polyubiquitinated N-ethylmaleimide-sensitive fusion (NSF) markedly increased I 5 min after retrieval while NSF protein levels decreased I h after retrieval in the synaptosomal membrane fraction in the nucleus accumbens (NAc) core. We then found that infusion of the proteasome inhibitor lactacystin into the NAc core prevented the impairment of memory reconsolidation induced by the protein synthesis inhibitor anisomycin and reversed the effects of anisomycin on NSF and glutamate receptor 2 (GluR2) protein levels in the synaptosomal membrane fraction in the NAc core. We also found that lactacystin infusion into the NAc core but not into the shell immediately after extinction training sessions inhibited CPP extinction and reversed the extinction training-induced decrease in NSF and GluR2 in the synaptosomal membrane fraction in the NAc core. Finally, infusions of lactacystin by itself into the NAc core immediately after each training session or before the CPP retrieval test had no effect on the consolidation and retrieval of cocaine reward memory. These findings suggest that ubiquitin-proteasome system-dependent protein degradation is critical for retrieval-induced memory destabilization. Neuropsychopharmacology (2013) 38, 778-790; doi:I0.1038/npp.2012.243; published online 16 January 2013
\end{abstract}

Keywords: cocaine; addiction; memory; reconsolidation; extinction; protein degradation

\section{INTRODUCTION}

Associative learning between environmental cues paired with drug taking and the rewarding effect of the drug forms a robust, persistent memory. Reexposure to drug-related cues after prolonged abstinence can reactivate the rewarding experience, elicit craving, and lead to relapse in humans (Childress et al, 1988; O'Brien et al, 1992) and rodents (Meil and See, 1996; Lu et al, 2004). Manipulating reward-related memories has become a promising potential method for treating addiction (Milton and Everitt, 2010).

Consolidated memory, once retrieved, enters a labile state and requires the maintenance of de novo synaptic protein synthesis (Tronson and Taylor, 2007; Nader and Hardt, 2009). A series of studies focused on the reconsolidation of reward memory (Lee et al, 2006; Bernardi et al, 2007; Fuchs et al, 2009; Ramirez et al, 2009; Yu et al, 2009; Li et al, 2010; Theberge et al, 2010). The memory of cocaineinduced conditioned place preference (CPP) undergoes

*Correspondence: Professor L Lu, National Institute on Drug Dependence, Peking University, 38 Xue Yuan Road, Beijing, 100191, China. Tel: +86 10 82802459, Fax: +86 10 62032624, E-mail: linlu@bjmu.edu.cn

${ }^{3}$ These authors contributed equally to this work.

Received 30 July 2012; revised 9 November 2012; accepted 19 November 2012; accepted article preview online 29 November 2012 reconsolidation and can be blocked by systemic anisomycin administration (Fan et al, 2010). However, the mechanism that underlies the transient labile state during the reconsolidation of cocaine reward memory is less well known.

Ubiquitin-proteasome system-mediated protein degradation mediates activity-dependent synaptic remodeling (Hegde et al, 1993; Jiang et al, 1998; Ehlers, 2003; Yi and Ehlers, 2005; Fonseca et al, 2006; Karpova et al, 2006; Fioravante et al, 2008) and is critical for memory formation and reconsolidation (Lopez-Salon et al, 2001; Artinian et al, 2008). In the contextual fear memory model in rats, an increase in polyubiquitinated hippocampal postsynaptic density (PSD) protein was detected after retrieval, and immediate infusion of a proteasome inhibitor into the hippocampal CA1 area prevented anisomycin-induced memory impairment and the extinction of fear memory, suggesting that ubiquitin-proteasome system-dependent protein degradation underlies destabilization processes after fear memory retrieval (Lee et al, 2008; Jarome et al, 2011).

Accumulating evidence suggests a critical role for $\alpha$-amino-3-hydroxy-5-methyl-4-isoxazolepropionic acid (AMPA) receptors in the nucleus accumbens (NAc) in cocaine-seeking behavior (Cornish and Kalivas, 2000; Anderson, 2008; Conrad et al, 2008; Famous et al, 2008). The PSD scaffolding protein $\mathrm{N}$-ethylmaleimide-sensitive 
fusion (NSF) protein, which interacts with the C-terminus of the AMPA glutamate receptor 2 (GluR2) subunit, has an important role in maintaining the surface expression of AMPA receptors and synaptic currents (Nishimune et al, 1998; Osten et al, 1998; Song et al, 1998; Noel et al, 1999; Lee et al, 2002). In the amygdala, disruption of the interaction between NSF and GluR2 impairs the formation of long-term fear memory (Joels and Lamprecht, 2010). The NAc core and shell, two subregions of the NAc, are considered to have differential roles in drug-associated behaviors. The NAc core is involved in the storage of reward-related information derived from conditioned reinforcers, whereas the NAc shell is essential for the motor-activating effects of stimulant drugs (Ito et al, 2004). Thus, dynamic changes in NSF protein levels in the NAc core may be involved in cocaine reward memory. We used a Pavlovian CPP procedure to study the role of protein degradation in the reconsolidation and extinction of cocaine reward-related associative memory. We hypothesized that the destabilization of cocaine reward memory induced by memory retrieval requires ubiquitin-proteasome system-mediated protein degradation in the NAc core, and synaptic cytoskeleton proteins, such as NSF, may be candidate targets that underlie this process.

\section{MATERIALS AND METHODS}

\section{Subjects}

Male Sprague-Dawley rats, weighing 240-260 g upon arrival, were housed in groups of five in a temperature-controlled $\left(23 \pm 2{ }^{\circ} \mathrm{C}\right)$ and humidity-controlled $(50 \pm 5 \%)$ animal facility. The rats were maintained on a 12-h/12-h light/dark cycle with ad libitum access to food and water. A total of 395 rats were used in the experiments described below. All of the experimental procedures were performed in accordance with the National Institutes of Health Guide for the Care and Use of Laboratory Animals, and the procedures were approved by the Local Animal Care and Use Committee.

\section{Drugs}

Cocaine hydrochloride was purchased from Qinghai Pharmaceutical (Xining, China). Lactacystin (Tocris, St Louis, MO, USA, cat. no. 2267), MG 132 ( $N$-[(phenylmethoxy) carbonyl]-L-leucyl- $N$-[(1S)-1-fromyl-3-methylbutyl]-L-leuci namide; Tocris, cat. no. 1748), and anisomycin (Alomone, Jerusalem, Israel, cat. no. A-520) were dissolved in $2 \%$ dimethylsulfoxide (DMSO) in artificial cerebrospinal fluid. All drugs were freshly prepared before the experiments.

\section{Surgery and Intracranial Injections}

The rats were anesthetized with sodium pentobarbital (50 mg/kg, i.p.), and permanent guide cannulae (23 gauge; Plastics One, Roanoke, VA, USA) were implanted bilaterally $1 \mathrm{~mm}$ above the NAc core and shell. The cannulae were angled toward the midline at a $16^{\circ}$ angle to avoid penetration of the lateral ventricle. The respective coordinates (Paxinos and Watson, 2005) were $1.5 \mathrm{~mm}$ anterior to bregma, $3.8 \mathrm{~mm}$ lateral to midline, and $6.0 \mathrm{~mm}$ ventral to flat skull surface (measured along the trajectory of the angled cannula) for the NAc core and $1.8 \mathrm{~mm}$ anterior, $3.2 \mathrm{~mm}$ lateral to midline, and $6.6 \mathrm{~mm}$ ventral to flat skull surface for the NAc shell (Xu et al, 2009). The rats were allowed to recover from surgery for 5-7 days. In experiments that did not involve western blots, the rats were anesthetized with sodium pentobarbital $(100 \mathrm{mg} / \mathrm{kg}$, i.p.) and transcardially perfused. Cannula placements were assessed using Nissl staining with thickness of $40 \mu \mathrm{m}$ under light microscopy. Seventeen subjects with misplaced cannulae were excluded. The locations of cannula tips of the rats are shown in Figure 1.

Injections were performed with Hamilton syringes, which were connected to 30-gauge injectors (Plastics One). Anisomycin $(62.5 \mu \mathrm{g}, 589 \mathrm{mM})$ in a $0.4-\mu \mathrm{l}$ volume, lactacystin $(32 \mathrm{ng}, 213 \mu \mathrm{M})$ in a $0.4-\mu \mathrm{l}$ volume, MG-132 (0.19 ng, $1 \mu \mathrm{M})$ in a $0.4-\mu$ l volume, or vehicle in a $0.4-\mu$ l volume was delivered bilaterally over a 1 -min period. The injection needle was kept in place for another 1 min to allow the drug to completely diffuse from the injector tips (Lu et al, 2005, 2009). The doses of lactacystin, MG132, and anisomycin were chosen based on the previous studies (Milekic et al, 2006; Merlo and Romano, 2007; Artinian et al, 2008; Lee, 2008; Lee et al, 2008).

\section{Conditioned Place Preference}

The CPP apparatus and training protocol have been described in our previous work (Li et al, 2010). In the baseline place preference test, the rats were initially placed in the middle chamber with the doors removed for $15 \mathrm{~min}$ (preconditioning test, Pre-C). Conditioning was performed using an unbiased, counterbalanced protocol as described in our previous work. In all, 36 of the 387 rats showed strong unconditioned side preference $(>540 \mathrm{~s}$ in any chamber) in the initial CPP baseline and were excluded from further experimentation. On the subsequent conditioning days, each rat was trained for 8 consecutive days with alternate injections of cocaine $(10 \mathrm{mg} / \mathrm{ml} / \mathrm{kg}$, i.p. $)$ and saline $(1 \mathrm{ml} / \mathrm{kg}$, i.p.). After each injection, the rat was confined to the cocaine- or saline-conditioned chamber for $45 \mathrm{~min}$ before being returned to its home cage. Subsequently, the expression of cocaine-induced CPP was tested 1 day after the last training session. The experimental conditions during the postconditioning tests (Post-C) were the same as those for the preconditioning test. The CPP score was defined as the time (in seconds) spent in the cocaine-paired chamber minus the time spent in the salinepaired chamber.

\section{Drug-Memory Reactivation}

The rats were freely reexposed to the previous CPP-trained chambers, allowed access to all compartments for $15 \mathrm{~min}$ to reactivate cocaine reward memory (Miller and Marshall, 2005), and then given the different experimental treatments (see below).

\section{Extinction Training}

One day after the postconditioning test, the rats were trained for an additional 8 consecutive days with saline $(1 \mathrm{ml} / \mathrm{kg}$, i.p.) but no cocaine injections. After each 
a

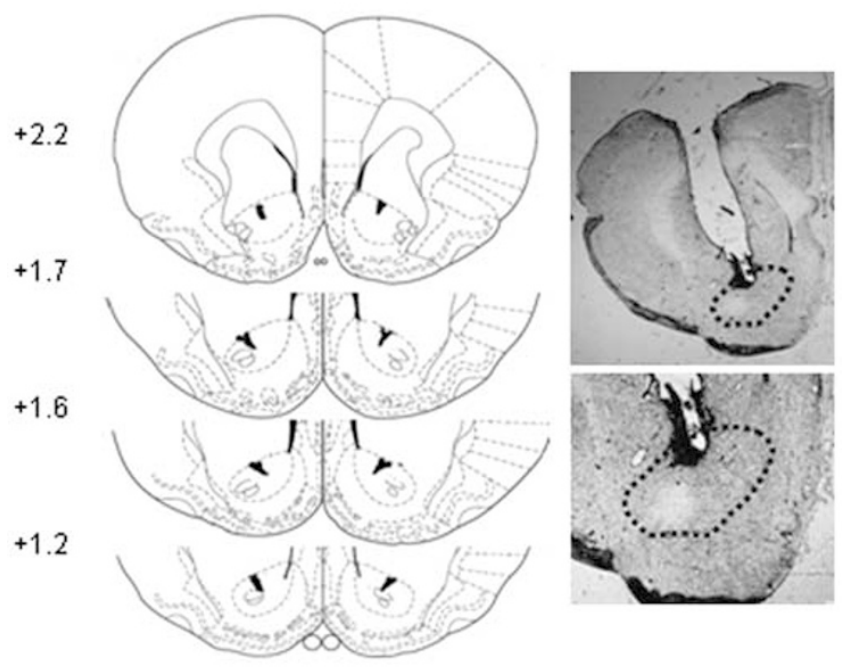

b

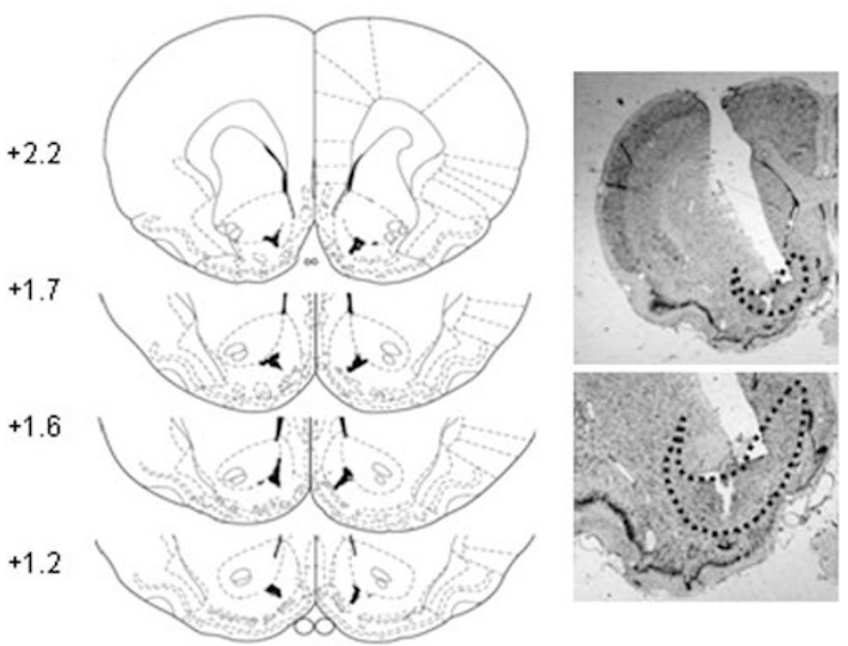

Figure I Schematic representation and photomicrographs of injection sites and potential damage in the nucleus accumbens core (a) and shell (b). The schematic representation (left column) begins with the most anterior injection site associated with the nucleus accumbens, and it shows that most needle tracks terminate within the nucleus accumbens, and tissue damage was generally confined to $0.1 \mathrm{~mm}$ around the needle tracks. The photomicrographs (right column) show that there is no significant tissue damage (characterized by gliosis and cell poor areas) around needle tracks.

injection, the rats were confined to the previous cocaine- or saline-conditioned chamber for $45 \mathrm{~min}$ before being returned to their home cages. Subsequently, the expression of CPP was tested 1 day after the last extinction training session (postextinction test, Post-E).

\section{Polyubiquitination Assay and Western Blotting}

The crude synaptosomal membrane fraction from the NAc core and shell was purified as described previously (Dunah and Standaert, 2001; Lee et al, 2008; Mao et al, 2009). Brains were removed, and the NAc core and shell were separately removed into a $1.5-\mathrm{ml}$ microtube that contained ice-cold homogenization buffer ( $0.32 \mathrm{M}$ sucrose, $4 \mathrm{mM}$ HEPES, $1 \mathrm{mM}$ EDTA, $1 \mathrm{mM}$ EGTA, pH 7.4) and a protease inhibitor cocktail. The sample was homogenized by sonication. The homogenate was centrifuged at $1000 \mathrm{~g}$ for $10 \mathrm{~min}$ at $4{ }^{\circ} \mathrm{C}$ to obtain the pellet (P1) that contained nuclei and large debris. The supernatant (S1) was again centrifuged at $10000 \mathrm{~g}$ for $30 \mathrm{~min}$ at $4{ }^{\circ} \mathrm{C}$ to generate a crude synaptosomal fraction (P2) and supernatant (S2). The crude synaptosomal membrane pellet (P2) was lysed hypo-osmotically and centrifuged at $25000 \mathrm{~g}$ for $30 \mathrm{~min}$ at $4{ }^{\circ} \mathrm{C}$ to generate the synaptosomal membrane fraction (LP1) and supernatant (LS1). The synaptosomal membrane fraction was solubilized and denatured in Tris-buffered saline (TBS) that contained $0.2 \%$ sodium dodecyl sulfate (SDS; $10 \mathrm{~min}$ at $70{ }^{\circ} \mathrm{C}$ ) diluted in $1 \%$ Triton X-100 and $5 \%$ glycerol and kept in protease inhibitor cocktail $(50 \mu \mathrm{M}$ MG132 and $10 \mu \mathrm{M}$ $\beta l a c)$. For binding, these samples (Input) were mixed with glutathione S transferase (GST)-agarose or GST-S5a agarose (Enzo Life Sciences, Farmingdale, NY, USA) and incubated for $2 \mathrm{~h}$ at $4{ }^{\circ} \mathrm{C}$. Bound proteins were washed extensively in TBS $+1 \%$ Triton $+5 \%$ glycerol and eluted by boiling in lithium dodecyl sulfate polyacrylamide gel electrophoresis (LDS-PAGE) sample buffer before LDS-PAGE (Nupage 4$12 \%$ Bis-Tris gels). The western blotting procedures were based on our previous studies (Lu et al, 2005; Li et al, 2008). $4 \times$ loading buffer (16\% glycerol, $20 \%$ mercaptoethanol, $2 \%$ SDS, and $0.05 \%$ bromophenol blue) was added to each sample (3:1, sample:loading buffer) before boiling for $3 \mathrm{~min}$. The samples were cooled and subjected to SDS-PAGE (10\% acrylamide/ $0.27 \% N, N^{\prime}$-methylenebisacryalamide resolving gel) for $\sim 40 \mathrm{~min}$ at $80 \mathrm{~V}$ in stacking gel and $\sim 1 \mathrm{~h}$ at $130 \mathrm{~V}$ in resolving gel. The proteins were electrophoretically transferred onto Immobilon-P transfer membranes (Millipore, Bedford, MA, USA) at $0.25 \mathrm{~A}$ for $2.5 \mathrm{~h}$. The membranes were then incubated overnight at $4{ }^{\circ} \mathrm{C}$ with antiubiquitin antibody ( $1: 500$; Santa Cruz Biotechnology, Santa Cruz, CA, USA, cat. no. 8017), anti-NSF antibody ( $1: 1000$; Cell Signaling, Danvers, MA, USA, cat. no. 2145), antiGluR2 antibody (1:1000; Millipore, cat. no. 07-598), PSD95 (1:1000; Santa Cruz, cat. no. 28941), and $\beta$-actin (1:1000; Santa Cruz, cat. no. 47778) and incubated for $45 \mathrm{~min}$ at room temperature on a shaker with horseradish peroxidase-conjugated secondary antibody (goat anti-rabbit IgG) diluted 1:5000 in blocking buffer. The immunostaining was visualized using the EZ-ECL Chemiluminescence detection kit. The blots were then exposed to X-ray film (Eastman Kodak Company) for 5-60 s. Values for the target protein levels were normalized to $\beta$-actin and analyzed with Quantity One software (version 4.4.0; Bio-Rad, Hercules, CA, USA).

\section{Data Analysis}

The data are expressed as mean \pm SEM and were analyzed using analysis of variance (ANOVA) with the appropriate between- and within-subjects factors for the different experiments (see Results). Significant main effects and interactions $(p<0.05)$ in the factorial ANOVAs were followed by simple ANOVAs and Tukey post hoc tests. We only report significant effects that are critical for the interpretation of the data in Results. For clarity, post hoc 
analyses are indicated by asterisks in the figures but are not described in Results.

\section{RESULTS}

Experiment 1: Effects of Cocaine Reward Memory Retrieval on the Polyubiquitination of Synaptosomal Membrane Proteins in the NAc

To determine the effects of memory retrieval on synaptosomal membrane proteins, we first performed a total protein polyubiquitination assay in the NAc core and shell after cocaine reward memory retrieval. The rats were divided into six groups ( $n=7-10$ per group): (1) naive group (ie, subjected only to daily handling in the home cage), (2) no retrieval group (ie, subjected to cocaineinduced CPP training without retrieval), (3) 15 min group (ie, subjected to cocaine-induced CPP training and then decapitated $15 \mathrm{~min}$ after retrieval), (4) $60 \mathrm{~min}$ group (ie, subjected to cocaine-induced CPP training and then decapitated $60 \mathrm{~min}$ after retrieval), (5) $2 \mathrm{~h}$ group (ie, subjected to cocaine-induced CPP training and then decapitated $2 \mathrm{~h}$ after retrieval), and (6) $24 \mathrm{~h}$ group (ie, subjected to cocaine-induced CPP training and then decapitated $24 \mathrm{~h}$ after retrieval). All of the rats were decapitated, and their brains were removed for subsequent determination of polyubiquitination level, NSF protein level, and NSF polyubiquitination level in the NAc core or shell (Figure 2a). Polyubiquitinated protein expression levels in the 15- and 60-min groups increased markedly in the NAc core (ANOVA, $\mathrm{F}_{4,34}=5.30, p<0.01$; Figure $2 \mathrm{~b}$, left column) but not in the NAc shell. These findings suggest that the retrieval of cocaine reward memory induced dynamic changes in protein polyubiquitination in the NAc core but not in the shell. Then, we focused on NSF, a type of PSD protein which has been showed to be involved in synaptic plasticity (Lee et al, 2002) and memory (Joels and Lamprecht, 2010), to further study the protein polyubiquitination after the retrieval of cocaine reward memory in the NAc core. We performed immunoblot analyses with antibodies against NSF using GST in complex with S5a (GST-S5a) in a pull-down assay. Polyubiquitinated NSF significantly increased 15 and $60 \mathrm{~min}$ after retrieval (oneway ANOVA, $\mathrm{F}_{4,34}=7.54, p<0.01$; Figure $2 \mathrm{c}$ ). Furthermore, NSF levels decreased 1 and $2 \mathrm{~h}$ after retrieval in the synaptosomal membrane region but returned to the baseline levels of no-retrieval animals at $24 \mathrm{~h}$ (one-way ANOVA, $\mathrm{F}_{4,34}=2.98, p<0.05$; Figure $2 \mathrm{~d}$ ). However, we did not observe the polyubiquitinated PSD-95 under basal conditions (Figure 2e). We also found no significant differences in total PSD-95 protein levels $(p>0.1)$ in the NAc core (Figure 2f) among five groups.

\section{Experiment 2: Protein Degradation Inhibition Blocks Anisomycin-Induced Reconsolidation Impairment After Cocaine Memory Retrieval}

In Experiment 1, we found that the retrieval of cocaine memory induced specific dynamic changes in protein polyubiquitination in the NAc core. We then sought to determine whether ubiquitin-proteasome system-dependent protein degradation in the NAc core has a role in retrieval- induced memory reconsolidation. To determine the specificity of the NAc core, we used the NAc shell as a control. In Experiment 2, we used eight groups of rats to determine the role of protein degradation in the NAc core (four groups, $n=10-12$ per group) and shell (four groups, $n=8-$ 11 per group) in the reconsolidation of cocaine reward memory (Figure 3a). After the establishment of cocaineinduced CPP, the rats were divided into eight groups that received different treatments in the NAc core and shell: (1) vehicle + vehicle, (2) lactacystin $(0.032 \mu \mathrm{g} /$ side $)+$ vehicle, (3) vehicle + anisomycin $(62.5 \mu \mathrm{g} /$ side), and (4) lactacystin $(0.032 \mu \mathrm{g} / \mathrm{side})+$ anisomycin $(62.5 \mu \mathrm{g} / \mathrm{side})$. A retest was conducted $24 \mathrm{~h}$ later. Fifteen minutes after the CPP test, all of the rats were decapitated, and only the NAc core, regardless of the infusion site, was removed for the subsequent determination of NSF and GluR2 protein levels in the synaptosomal membrane fraction (LP1 fraction). We focused on the NAc core because the core, not the shell, is critical for the reconsolidation and maintenance of cocaine cue memory (Miller and Marshall, 2005; Li et al, 2011). Furthermore, in Experiment 1, we found that polyubiquitinated protein expression levels in the 15- and 60-min groups markedly increased in the NAc core but not in the shell.

After 8 days of CPP training, all of the groups developed cocaine-induced CPP $\left(\mathrm{F}_{1,39}=77.04, p<0.01\right.$; Figure $\left.3 \mathrm{~b}\right)$. No differences were found between these groups $(p>0.05)$. The CPP score data from the posttreatment test (Post-T) for the NAc core and shell injections were analyzed with a two-way ANOVA that included the between-subjects factors lactacystin (vehicle, lactacystin) and anisomycin (vehicle, anisomycin). This analysis revealed a significant interaction between these two factors $\left(\mathrm{F}_{1,39}=4.43, p<0.05\right.$; Figure $3 \mathrm{c}$, left column) in the NAc core. The analyses of immediate NAc shell injections revealed no significant effects of lactacystin, anisomycin, or lactacystin $\times$ anisomycin interaction ( $p>0.05$; Figure $3 c$, right column). The analyses of the western blot data included the between-subject factors lactacystin (vehicle, lactacystin) and anisomycin (vehicle, anisomycin). The analyses of NSF and GluR2 in the NAc core in rats that received NAc core injections revealed a significant interaction between the two factors $\left(\mathrm{F}_{1,39}=45.13, p<0.01\right.$ and $\mathrm{F}_{1,39}=27.99, p<0.01$, respectively; Figure $3 \mathrm{~d}$ and e, left columns). No significant effects on NSF and GluR2 levels in the NAc core were observed for the rats that received NAc shell injections $(p>0.05$; Figure $3 \mathrm{~d}$ and e, right columns). Post hoc group differences are shown in Figure 3. Thus, the proteasome inhibitor lactacystin injected into the NAc core reversed the impairment effect of anisomycin on cocaine-induced CPP and memory retrieval-induced decreases in NSF and GluR2 protein levels in the synaptosomal membrane in the NAc core.

\section{Experiment 3: Further Confirmation of the Role of Protein Degradation in the NAc Core in the Reconsolidation of Cocaine Reward Memory}

We used 16 groups of rats to further confirm the role of NAc core protein degradation in the reconsolidation of cocaine-induced CPP (Figures 4 and 5). First, we used four groups ( $n=7-9$ per group) to determine whether MG132, 


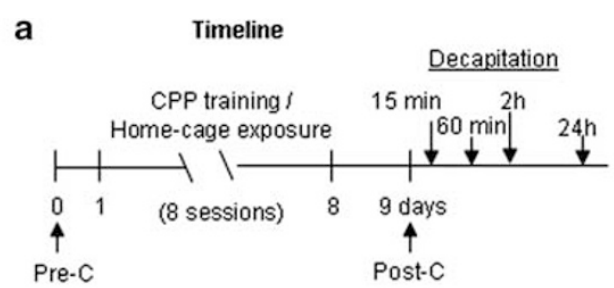

b
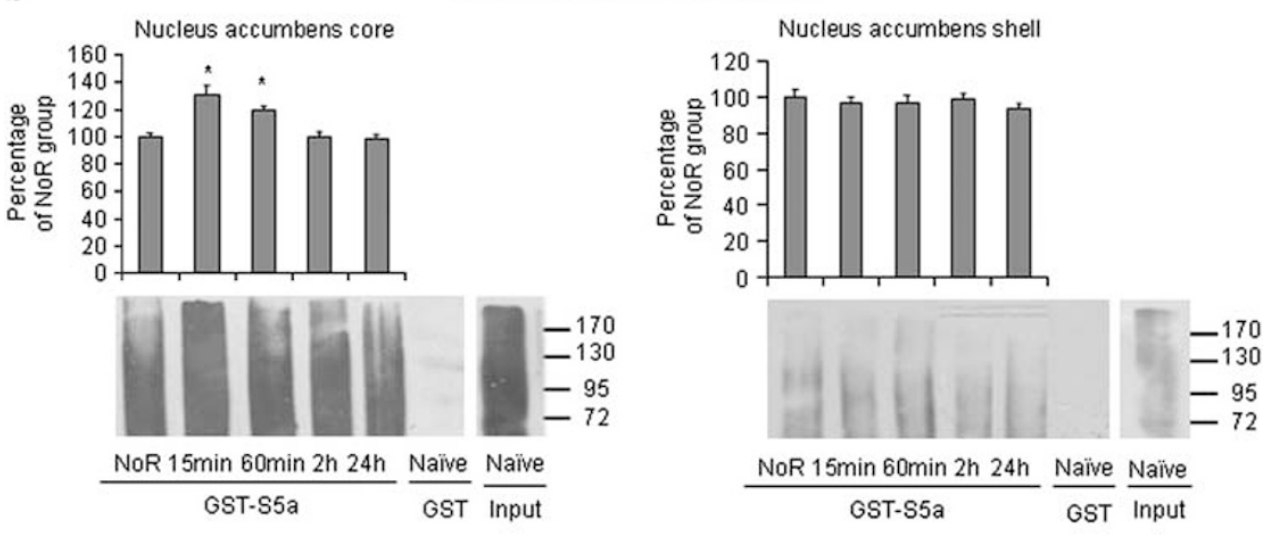

C NSF polyubiquitination level in NAC core

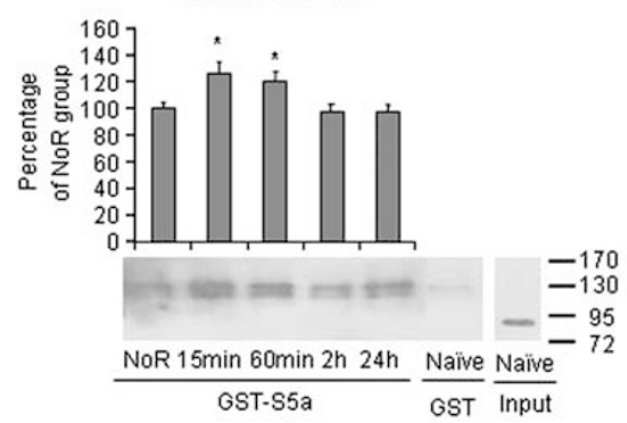

d

NSF protein level
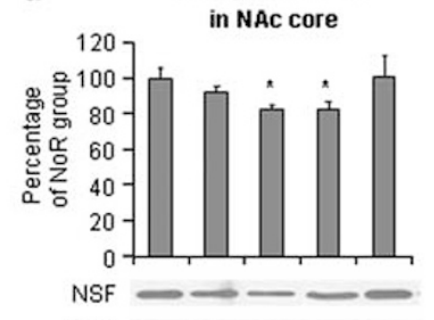

actin $-\frac{}{\text { NoR } 15 \min 60 \min 2 \mathrm{~h}}-\frac{}{24 \mathrm{~h}}$

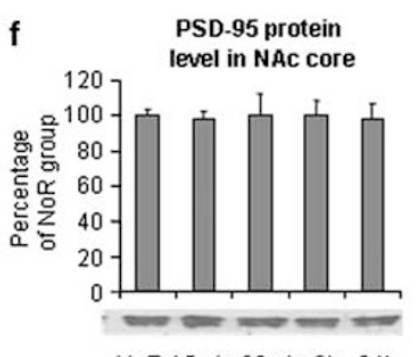

NoR $15 \min 60 \min 2 \mathrm{~h} \quad 24 \mathrm{~h}$

Figure 2 Memory retrieval significantly increases polyubiquitination in the NAc core synaptosomal membrane fraction. (a) Timeline of the experiment. The rats were divided into six groups ( $n=7-10$ per group): naive group (ie, subjected only to daily handling in the home cage), no retrieval group (ie, subjected to cocaine-induced CPP training without retrieval), 15 min group (ie, subjected to cocaine-induced CPP training and then decapitated I5 min after retrieval), 60 min group (ie, subjected to cocaine-induced CPP training and then decapitated $60 \mathrm{~min}$ after retrieval), $2 \mathrm{~h}$ group (ie, subjected to cocaineinduced CPP training and then decapitated $2 \mathrm{~h}$ after retrieval), and $24 \mathrm{~h}$ group (ie, subjected to cocaine-induced CPP training and then decapitated $24 \mathrm{~h}$ after retrieval). All of the rats were decapitated, and their brains were removed for the subsequent determination of polyubiquitination levels, NSF protein levels, and NSF polyubiquitination levels in the NAc core and shell. (b) Effect of retrieval on polyubiquitination in the NAc core and shell. (c-f) Effect of retrieval on protein levels of polyubiquitinated NSF (c), total NSF (d), polyubiquitinated PSD-95 (e), and total PSD-95 (f) in the NAc core. The data are expressed as a percentage (mean \pm SEM) of the values of the NoR group. ${ }^{*} p<0.05$, compared with NoR group. $n=7-10$ per group. NoR, no retrieval group; Pre-C, preconditioning test; Post-C, postconditioning test.

another proteasome inhibitor, mimics the effect of lactacystin by reversing the effect of anisomycin on reconsolidation. The protocol was the same as in Experiment 2, with the exception that lactacystin was replaced with MG132 (Figure 4a). After 8 days of CPP training, all of the groups developed cocaine-induced $\mathrm{CPP} \quad\left(\mathrm{F}_{1,28}=78.47, p<0.01\right.$; Figure $4 \mathrm{~b}$, left column). No differences were found between these groups $(p>0.05)$. The CPP score data from the posttreatment test for the NAc core injections were analyzed with a two-way ANOVA that included the between-subjects factors MG132 (vehicle, MG132) and anisomycin (vehicle, anisomycin). This analysis revealed a significant MG132 $\times$ anisomycin interaction $\left(\mathrm{F}_{1,28}=5.76, p<0.05\right.$; Figure $4 \mathrm{~b}$, right column) in the NAc core. Post hoc group differences 
are shown in Figure $4 \mathrm{~b}$. These results indicate that MG132 mimicked the effects of lactacystin and reversed the effect of anisomycin on reconsolidation.

Then, we used another four groups ( $n=6-9$ per group) to determine whether the effect of lactacystin is retrieval dependent. The protocol was the same as in Experiment 2, with the exception that the rats did not undergo a memory retrieval test before NAc core infusions (Figure 5a, left column). After 8 days of CPP training, all of the groups developed cocaine-induced $\operatorname{CPP} \quad\left(\mathrm{F}_{1,27}=77.86, p<0.01\right.$;

a

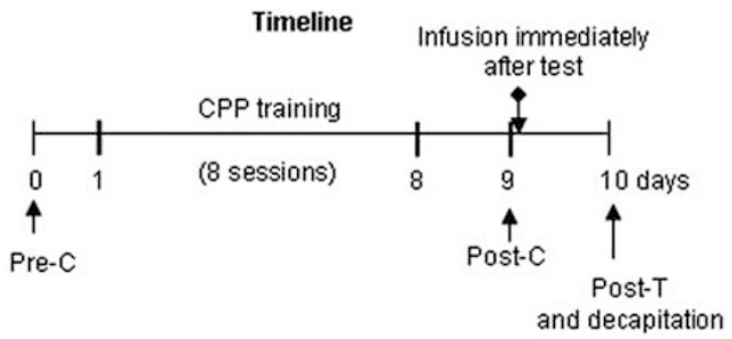

$\square$ Vehicle + Vehicle $\square$ Lactacystin + Vehicle

$\boldsymbol{\Delta}$ Vehicle + Anisomycin $\Delta$ Lactacystin + Anisomycin

b

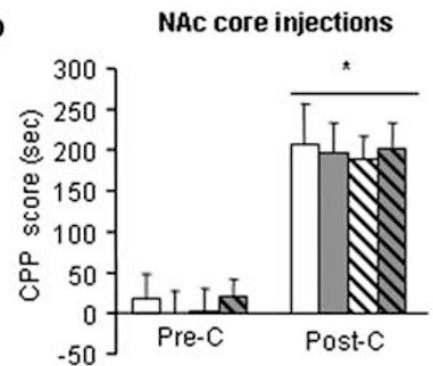

C
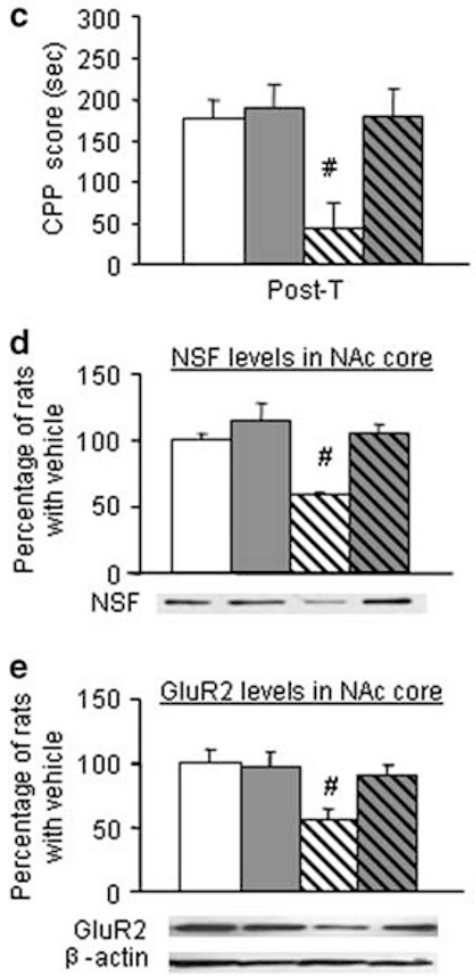

NAC shell injections
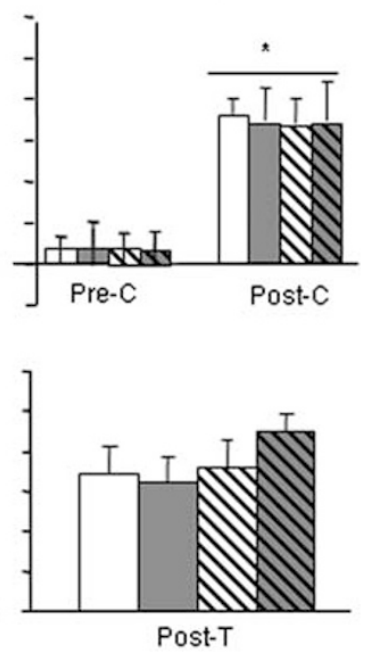

NSF levels in NAc core
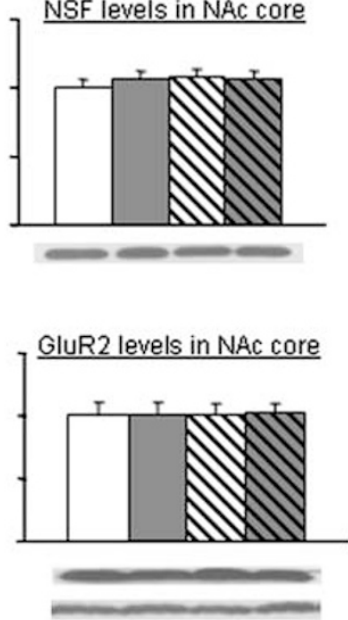

Figure 5a, right column). No differences were found between these groups $(p>0.05)$. The CPP score data from the posttreatment test for the NAc core injections were analyzed with a two-way ANOVA that included the between-subjects factors lactacystin (vehicle, lactacystin)

a

Timeline

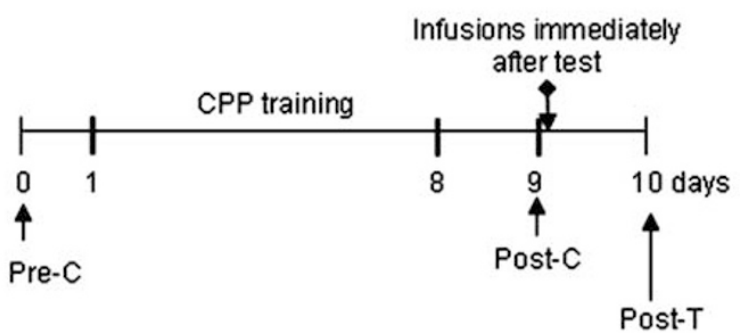

b

NAc core injections

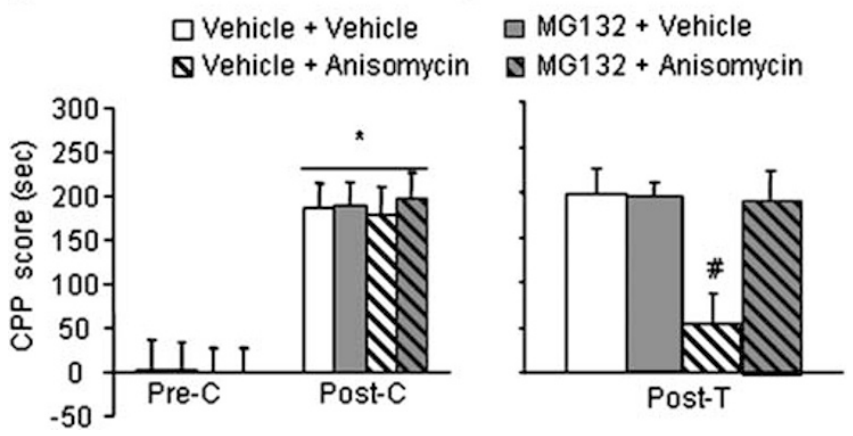

Figure 4 MGI32 mimics the effects of lactacystin on the reconsolidation of cocaine reward memory by blocking anisomycin-induced memory impairment after retrieval. (a) Timeline of the experiments. After the establishment of cocaine-induced CPP, the rats were divided into four groups that received different treatments in the NAc core. A retest was conducted $24 \mathrm{~h}$ later. (b) Mean \pm SEM CPP scores during preconditioning test, postconditioning test, and $24 \mathrm{~h}$ posttreatment test in rats that received microinfusions into the NAc core immediately after the retrieval test. $n=7-9$ per group. ${ }^{*} p<0.05$, compared with the CPP score of preconditioning test; ${ }_{p} p<0.05$, compared with the other three groups. Pre-C, preconditioning test; Post-C, postconditioning test; Post-T, posttreatment test.

Figure 3 Inhibition of protein degradation by lactacystin in the NAc core but not in the shell blocks anisomycin-induced impairment of cocaine memory reconsolidation and decreases of NSF and GluR2 levels in NAc core. (a) Timeline of the experiment. After the establishment of cocaineinduced CPP, the rats were divided into eight groups that received different treatments in the NAc core and shell. A retest was conducted $24 \mathrm{~h}$ later. Fifteen minutes after the CPP test, all of the rats were decapitated, and only the NAc core, regardless of the infusion site, was removed for the subsequent determination of NSF and GluR2 protein levels in the synaptosomal membrane fraction ( $\mathrm{LPI}$ fraction). (b, c) Inhibition of protein degradation by lactacystin in the NAc core but not in the shell blocks anisomycin-induced impairment of cocaine memory reconsolidation. Mean \pm SEM CPP scores during baseline preference, posttraining, and posttreatment in rats that received microinfusions into the NAc core and shell. $* p<0.05$, compared with the CPP score of preconditioning test; ${ }^{\#} p<0.05$, compared with the other three groups. $n=8-12$ per group. ( $d, e)$ Inhibition of protein degradation by lactacystin in the NAc core but not in the shell blocks anisomycin-induced deceases in NSF (d) and GluR2 (e) in the NAc core after memory retrieval. The data are expressed as a percentage (mean \pm SEM) of the values of the rats that received vehicle injection. $n=8-12$ per group. ${ }^{\#} p<0.05$, compared with the other three groups. Pre-C, preconditioning test; Post-C, postconditioning test; Post-T, posttreatment test. 


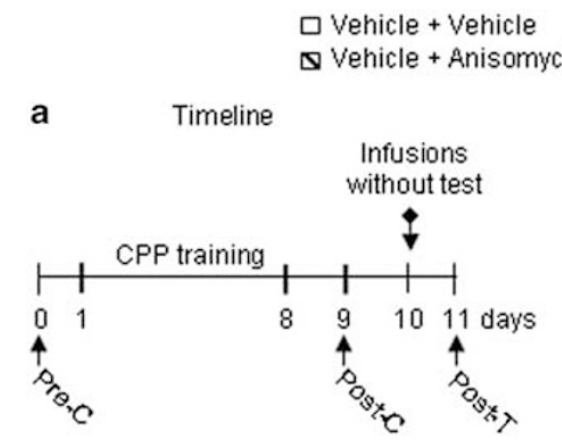

$\square$ Lactacystin + Vehicle
$\boldsymbol{\Delta}$ Lactacystin + Anisomycin

CPP score

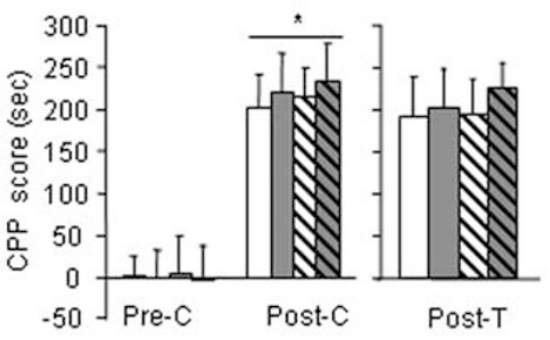

b Timeline
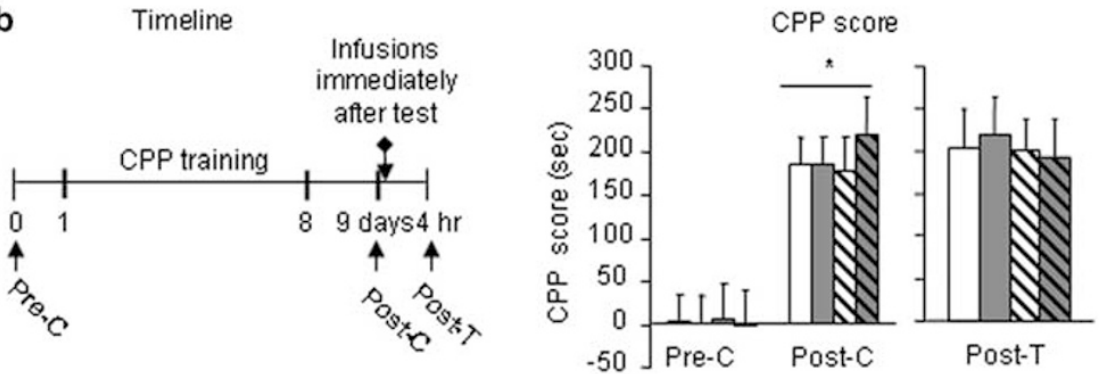

c Timeline
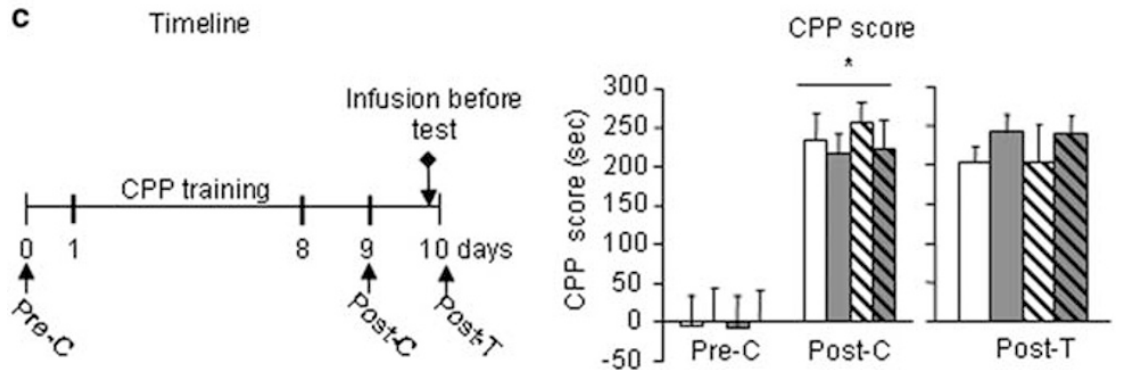

Figure 5 Further confirmation of the role of protein degradation in the reconsolidation of cocaine cue memory. (a-c, left column) Timeline of the experiments. (a, right column) Mean \pm SEM CPP scores during the preconditioning test, postconditioning test, and $24 \mathrm{~h}$ posttreatment test in rats that received microinfusions into the NAc core without a retrieval test. $n=6-9$ per group. (b, right column) Mean \pm SEM CPP scores during the preconditioning test, postconditioning test, and $4 \mathrm{~h}$ posttreatment test in rats that received microinfusions into the NAc core immediately after retrieval. $n=6-7$ per group. (c, right column) Mean \pm SEM CPP scores during the preconditioning test, postconditioning test, and posttreatment test in rats that received microinfusions into the NAc core immediately before retrieval. $n=6-8$ per group. ${ }^{*} p<0.05$, compared with the CPP score of preconditioning test. Pre-C, preconditioning test; Post-C, postconditioning test; Post-T, posttreatment test.

and anisomycin (vehicle, anisomycin). This analysis revealed no significant lactacystin $\times$ anisomycin interaction $(p>0.05)$ in the NAc core. These results indicate that the effect of anisomycin and lactacystin on cocaine reward memory was retrieval dependent. Next, we used four groups ( $n=6-7$ per group) to determine whether lactacystin infusion affects postretrieval short-term memory. Protein synthesis inhibition has been previously shown to disrupt postretrieval long-term memory ( $24 \mathrm{~h}$ memory after retrieval) but not postretrieval short-term memory $(4 \mathrm{~h}$ memory after retrieval; Nader et al, 2000). We examined whether anisomycin or lactacystin administration immediately after retrieval impairs the postretrieval short-term memory of cocaine. The protocol was the same as in Experiment 2, with the exception that the rats were retested $4 \mathrm{~h}$ after retrieval (Figure 5b, left column). After 8 days of CPP training, all of the groups developed cocaine-induced CPP $\left(\mathrm{F}_{1,22}=63.05\right.$, $p<0.01$; Figure $5 \mathrm{~b}$, right column). No differences were found between these groups $(p>0.05)$. The CPP score data from the posttreatment test for the NAc core injections were analyzed with a two-way ANOVA that included the between-subjects factors lactacystin (vehicle, lactacystin) and anisomycin (vehicle, anisomycin). This analysis revealed no significant lactacystin $\times$ anisomycin interaction $(p>0.05)$ in the NAc core. These results indicate that lactacystin and anisomycin had no effects on postretrieval short-term memory. Finally, we used four groups $(n=6-8$ per group) to determine whether protein degradation inhibition affects memory retrieval. Four groups of rats received 8 days of training and underwent the CPP test on day 9. The CPP test was conducted immediately after the infusions (Figure $5 \mathrm{c}$, left column). After 8 days of CPP training, all of the groups developed cocaine-induced CPP $\left(\mathrm{F}_{1,25}=50.56, \quad p<0.01\right.$; Figure $5 \mathrm{c}$, right column $)$. No differences were found between these groups $(p>0.05)$. The CPP score data from the posttreatment test were analyzed with a two-way ANOVA that included the between-subjects factors lactacystin (vehicle, lactacystin) and anisomycin (vehicle, anisomycin). This analysis revealed no lactacystin $\times$ anisomycin interaction $(p>0.05$; 
Figure $5 c$, right column) in the NAc core. These results indicate that lactacystin and anisomycin injections into the NAc core had no effect on retrieval itself.

\section{Experiment 4: Effect of Protein Degradation Inhibition in the NAc on the Extinction of Cocaine Reward Memory}

We used eight groups of rats to determine the role of protein degradation in the NAc core (four groups, $n=8-10$ per group) and shell (four groups, $n=9-10$ per group) in the extinction of cocaine CPP (Figure 6a). All of the rats received 8 days of CPP training, were randomly divided into four groups, and received different treatments on subsequent days: (1) lactacystin + extinction training, (2) lactacystin + no extinction training, (3) vehicle + extinction training, and (4) vehicle + no extinction training. The extinction training lasted for 8 days, and the infusions were given immediately after every session of extinction training. The rats that did not undergo extinction training received respective infusions and then were left in their home cages. On day 18, the rats were retested for CPP. Fifteen minutes after the CPP test, all of the rats were decapitated, and only the NAc core was removed for the subsequent determination of NSF and GluR2 protein levels in the synaptosomal membrane fraction (LP1 fraction) using western blotting. Additionally, we also used Nissl staining to determine the localization of the injections, potential tissue damage, and scar tissue after repeated infusions. We did not observe obvious tissue damage (Figure 1), indicating that our findings were not attributable to brain region dysfunction.

After 8 days of CPP training, all of the groups developed cocaine-induced $\mathrm{CPP} \quad\left(\mathrm{F}_{1,34}=70.52, p<0.01\right.$ for core; $\mathrm{F}_{1,36}=119.34, \quad p<0.01$ for shell; Figure $6 \mathrm{~b}$ ), and no differences were found between these groups $(p>0.05)$. The CPP score data from the postextinction test for the NAc core and shell injections were analyzed with a two-way ANOVA that included the between-subjects factors

Figure 6 Inhibition of protein degradation by lactacystin in the NAc core but not in the shell prevents extinction of cocaine reward memory and decreases of NSF and GluR2 levels induced by extinction training. (a) Timeline of the experiment. All of the rats received 8 days of CPP training, were randomly divided into four groups, and received different treatments on subsequent days: lactacystin + extinction training, lactacystin + no extinction training, vehicle + extinction training, and vehicle + no extinction training. The extinction training lasted for 8 days, and the infusions were given immediately after every session of extinction training. On day 18, the rats were retested for CPP. Fifteen minutes after the CPP test, all of the rats were decapitated, and only the NAc core was removed for the subsequent determination of NSF and GluR2 protein levels in the synaptosomal membrane fraction (LPI fraction). (b, c) Inhibition of protein degradation by lactacystin in the NAc core but not in the shell prevents extinction of cocaine reward memory. Mean \pm SEM CPP scores during preconditioning, posttraining, and postextinction in rats that received microinfusions into the NAc core and shell, respectively. ${ }^{*} p<0.05$, compared with the CPP score of preconditioning test; ${ }^{\#} p<0.05$, compared with the other three groups. $n=8-10$ per group. (d, e) Inhibition of protein degradation by lactacystin in the NAc core but not in the shell blocks the decrease of NSF (d) and GluR2 (e) levels in NAc core induced by extinction training. The data are expressed as a percentage (mean \pm SEM) of the values of rats that underwent no extinction + vehicle. $n=8-10$ per group. ${ }^{\#} p<0.05$, compared with the other three groups. Pre-C, preconditioning test; PostC, postconditioning test; Post-E, postextinction test. lactacystin (vehicle, lactacystin) and extinction training (yes, no). This analysis revealed a significant effect of extinction training $\left(\mathrm{F}_{1,34}=10.61, \quad p<0.01\right)$ and a lactacystin $\times$ extinction interaction $\left(\mathrm{F}_{1,34}=4.67, p<0.05\right.$; Figure $6 c$, left column) in the NAc core. The analyses of immediate NAc shell injections (Figure 6c) revealed a significant effect of extinction training $\left(\mathrm{F}_{1,36}=15.20\right.$, $p<0.01)$ but no lactacystin $\times$ extinction interaction ( $p>0.05$; Figure $6 c$, right column). The analyses of the western blot data included the between-subject factors lactacystin (vehicle, lactacystin) and extinction training (yes, no). The analyses of NSF and GluR2 levels in the
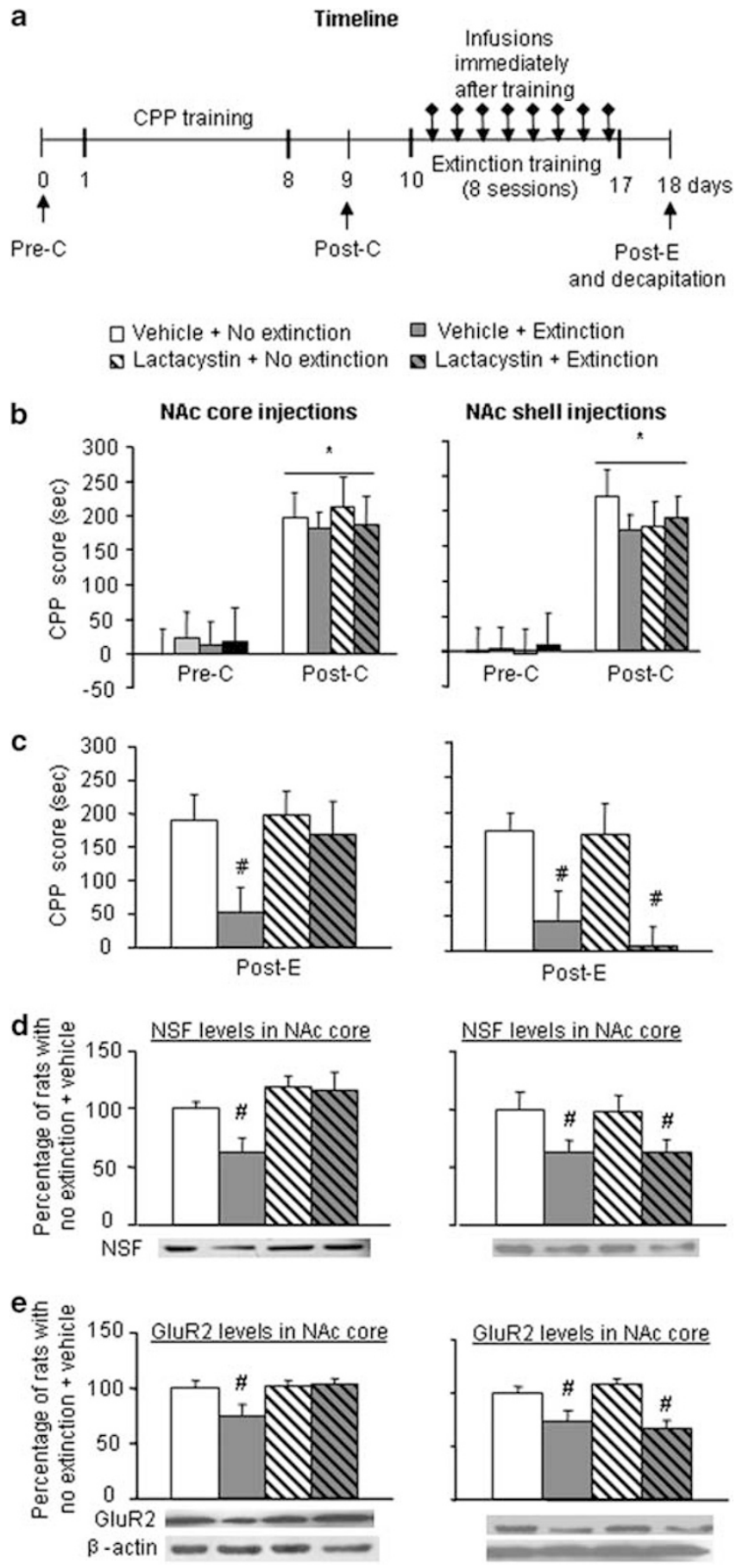
NAc core in rats that received NAc core injections revealed a significant lactacystin $\times$ extinction interaction $\left(F_{1,34}=31.69, p<0.01\right.$ and $F_{1,34}=89.47, p<0.01$, for NSF and GluR2, respectively; Figure $6 \mathrm{~d}$ and e, left columns). The analyses of NSF and GluR2 levels in the NAc core in rats that received NAc shell injections revealed a significant effect of extinction training $\left(\mathrm{F}_{1,36}=53.74, p<0.01\right.$ and $\mathrm{F}_{1,36}=182.78, p<0.05$, for NSF and GluR2, respectively; Figure $6 \mathrm{~d}$ and e, right columns) but no lactacystin $\times$ extinction interaction $(p>0.05)$. Post hoc group differences are shown in Figure 6. Thus, the proteasome inhibitor lactacystin injected into the NAc core but not into the shell reversed the effect of extinction training on cocaine-induced CPP and NSF and GluR2 protein levels in the synaptosomal membrane in the NAc core.

Both reconsolidation and extinction are initiated by memory retrieval, and retrieval-induced plasticity allows new information to be integrated into the initial memory representation (Hupbach et al, 2007; Schiller et al, 2010). Thus, our findings in Experiments 1-3 indicated that ubiquitin-proteasome system-dependent protein degradation is involved in the integration of new information in the existing cocaine reward memory. We then investigated whether ubiquitin-proteasome system-dependent protein degradation is also involved in the encoding of new reward information (ie, formation of cocaine reward memory). Four groups of rats ( $n=7-9$ per group) were injected with either vehicle or lactacystin into the NAc core or shell immediately after the each training session. The test for the expression of cocaine-induced CPP was performed 1 day after the last training day (Figure 7a). The CPP score data from the postconditioning test for the NAc core and shell injections were analyzed using a two-way ANOVA that included the between-subjects factor lactacystin (vehicle, lactacystin) and within-subjects factor test phase (preconditioning CPP test and postconditioning CPP test). This analysis revealed a significant effect of test phase (NAc core, $\mathrm{F}_{1,15}=9.88, p<0.01$, Figure $7 \mathrm{~b}$; NAc shell, $\mathrm{F}_{1,16}=10.32$, $p<0.01$, Figure 7c) but no lactacystin $\times$ test phase interaction $(p>0.05)$. These results indicate that posttraining intra-NAc injection of lactacystin had no effect on the formation of cocaine reward memory.

\section{DISCUSSION}

We investigated the role of ubiquitin-proteasome systemmediated protein degradation in cocaine reward memory, as assessed in the CPP procedure. We found that polyubiquitinated protein expression levels and polyubiquitinated NSF markedly increased $15 \mathrm{~min}$ after retrieval, whereas NSF protein levels decreased $1 \mathrm{~h}$ after retrieval in the synaptosomal membrane fraction in the NAc core, and all the alterations returned to baseline levels $24 \mathrm{~h}$ later. We then found that infusion of the proteasome inhibitor lactacystin into the NAc core prevented protein synthesis inhibitor anisomycin-induced impairment of memory reconsolidation and reversed anisomycin's effect on NSF and GluR2 protein levels in the synaptosomal membrane fraction in the NAc core. We also found that lactacystin infusion into the NAc core but not into the shell immediately after extinction training sessions inhibited
Timeline

Infusions immediately after training

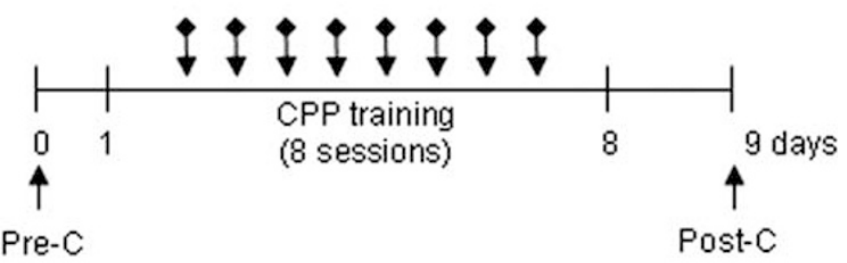

b

NAC core injections

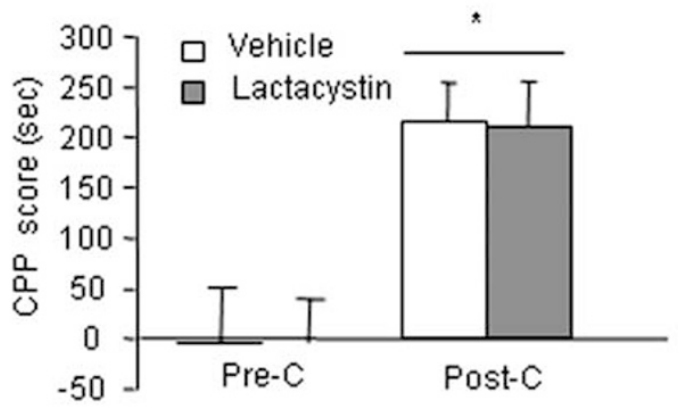

C

NAc shell injections

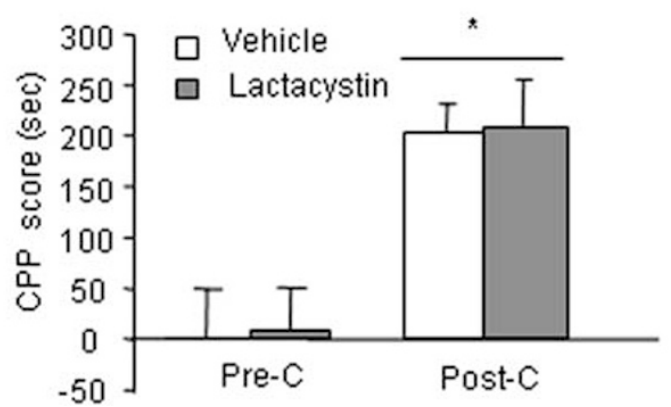

Figure 7 Inhibition of protein degradation by lactacystin in the NAc core and shell had no effect on the formation of cocaine reward memory. (a) Timeline of the experiment. Four groups of rats were injected with either vehicle or lactacystin into the NAc core or shell immediately after each training session. The test for the expression of cocaine-induced CPP was performed I day after the last training day. (b, c) Inhibition of protein degradation by lactacystin in the NAc core and shell had no effect on formation of cocaine reward memory. The data are expressed as the mean \pm SEM CPP scores during preconditioning and posttraining in rats that received microinfusions into the NAc core and shell, respectively. ${ }^{*} p<0.05$, compared with the CPP score of the preconditioning test. $n=7$ 9 per group. Pre-C, preconditioning test; Post-C, postconditioning test.

extinction training and reversed the extinction training induced decrease of NSF and GluR2 in the synaptosomal membrane fraction in NAc core.

The role of ubiquitin-proteasome system-mediated protein degradation in the destabilization of cocaine reward memory after reexposure to a cocaine-paired context is anatomically and behaviorally specific. First, the effects of lactacystin and anisomycin were specific to the NAc core. Anisomycin infusion into the NAc core but not into the shell disrupted the subsequent expression of cocaineinduced CPP $24 \mathrm{~h}$ but not $4 \mathrm{~h}$ later, accompanied by reduced NSF and GluR2 levels in the NAc core. Infusion of the 
proteasome inhibitor MG132 or lactacystin into the NAc core reversed the effect of anisomycin. Second, the protein expression data showed time-dependent alterations in polyubiquitinated protein levels in the NAc core but not in the shell. The NAc core is a component of the neural circuitry involved in the storage of reward-related information derived from conditioned reinforcers, whereas the NAc shell is essential for the motor-activating effects of stimulant drugs (Ito et al, 2004). Our findings are consistent with previous studies that showed that the NAc core but not the shell mediates the reconsolidation and storage of drug cue memories (Miller and Marshall, 2005; Li et al, 2011) and support the hypothesis that the NAc core and shell have differential roles in drug-associated behaviors. Interestingly, basal levels of ubiquitination are much lower in the NAc shell than in the NAc core. In fact, the protein concentration of the shell samples was less than that of the core samples. The second reason may be differences in the structure and morphology of principal cells in the NAc core and shell. The major targeted brain regions in our studies were the medial shell and core. The principal neurons in the medial shell have fewer dendritic arbors, fewer spines, and as much as $80 \%$ less surface available for synaptic contact compared with neurons in the NAc core (Meredith et al, 1992, 2008). Therefore, the total turnover of synaptic proteins may be much lower in the NAc shell than in the NAc core. We excluded the possibility that protein degradation affects postretrieval short-term memory and the storage and retrieval of cocaine reward memory. Anisomycin failed to disrupt the memory when it was injected without memory reactivation, and neither anisomycin nor lactacystin influenced postretrieval short-term memory or memory retrieval.

Anisomycin's effects on memory reconsolidation and the protein levels of NSF and GluR2 in our study were specific. First, the decrease in NSF and GluR2 levels was not attributable to the CPP test before kill. In Experiment 2, the rats were killed $15 \mathrm{~min}$ after the CPP test, with no significant decrease in NSF levels within $15 \mathrm{~min}$ (see Experiment 1). Furthermore, all four groups underwent the CPP test. If the reduction of NSF levels was induced by a retrieval session but not by anisomycin, then no significant difference in NSF levels would be found between these groups. Second, the decrease in NSF/GluR2 levels was not attributable to persistent inhibition of baseline protein levels induced by anisomycin. The inhibitory effect of anisomycin is transient (Rosenblum et al, 1993), and infusions of anisomycin had no effect on protein levels (eg, ERK2, Fos, CaMKII $\alpha, \mathrm{AKT}$, and Homer 1a) $12 \mathrm{~h}$ later (Bekinschtein et al, 2010). In our study, we infused anisomycin after CPP retrieval, and we detected protein levels $24 \mathrm{~h}$ later. So, we considered that anisomycin injections had no effect on baseline levels of NSF/GluR2, and the decrease in NSF/GluR2 was due to inhibiting protein synthesis during reconsolidation of drug CPP. Altogether, these findings suggest that ubiquitin-proteasome-dependent protein degradation underlies the destabilization processes induced by memory retrieval and is critical both for the reconsolidation and for the extinction of cocaine reward memory.

Our study was inspired by the work of Lee et al (2008). By examining the reconsolidation of conditioned fear memory in mice, they observed an increase in polyubiquitinated
Shank and GKAP but not PSD-95 in the mouse hippocampus $1 \mathrm{~h}$ after the retrieval of fear memory. They also found that infusion of lactacystin into the CA1 region of the hippocampus rescued the memory impairment induced by anisomycin during the reconsolidation of contextual fear memory in mice, and lactacystin infusions prevented the extinction of fear memory. In the present study, we found dynamic changes in polyubiquitinated proteins and NSF levels in the NAc core after memory retrieval. We then found that anisomycin infusions into the NAc core but not into the shell after cocaine memory retrieval impaired reconsolidation and produced a very robust (50\%) reduction of NSF and GluR2 levels in the NAc core. Thus, after retrieval, some PSD proteins, such as NSF, may become labile and degrade, and the cocaine memory trace may become labile. New protein synthesis then occurs. The proteins that were degraded may return to their original levels, thus reconsolidating the cocaine memory trace. Protein synthesis blockade may reveal their degradation (ie, lower protein levels), thus impairing cocaine reward memory. If protein synthesis is blocked while their degradation is also prevented, then no overall changes occur in protein levels and CPP performance.

Interestingly, infusion of the proteasome inhibitor alone immediately after memory retrieval had no significant effect on subsequent memory strength. One explanation for this finding is that $10 \mathrm{mg} / \mathrm{kg}$ cocaine-induced CPP may reach a ceiling effect in the CPP test. In our previous study, we observed a ceiling effect with $10 \mathrm{mg} / \mathrm{kg}$ morphine-induced CPP (Li et al, 2008), and we presume that $10 \mathrm{mg} / \mathrm{kg}$ cocaineinduced CPP may also reach such a ceiling. Additionally, Bardo et al (1995) found that cocaine tended to produce an inverted U-shaped function, in which no significant differences in the strength of CPP produced by doses of $0.1-10 \mathrm{mg} / \mathrm{kg}$ were observed. This indicates that the strength of cocaine-induced CPP cannot be further elevated when it reaches a certain level. Infusion of the proteasome inhibitor alone immediately after memory retrieval may enhance the strength of the subsequent memory, but the putative effect was not behaviorally detected. Therefore, the proteasome inhibitor could not further increase CPP scores. Another explanation is that some other mechanisms may also mediate the destabilization of the memory trace after retrieval, such as $N$-methyl-D-aspartate receptors (Ben Mamou et al, 2006). These mechanisms may to some extent compensate for the role of ubiquitin-proteasome systemmediated protein degradation when the ubiquitin-proteasome system-mediated protein degradation is inhibited by lactacystin. Altogether and consistent with the notion of the time-dependent nature of memory reconsolidation (Nader et al, 2000), our findings suggest that ubiquitin-proteasome system-mediated protein degradation in the NAc core underlies a relatively early stage of synaptic remodeling after the retrieval of cocaine reward memory.

Memory retrieval can initiate two opposing processes: reconsolidation and extinction (Eisenberg et al, 2003; Pedreira and Maldonado, 2003; Suzuki et al, 2004). In the present study, we also investigated the role of protein degradation in memory destabilization in the extinction of cocaine reward memory. We found that after eight sessions of extinction training, NSF and GluR2 levels decreased in the NAc core, and lactacystin infusions into the NAc core 
prevented the effect of extinction training. Our data suggest that protein degradation has an important role in extinction training. Extinction is thought to reflect the formation of new inhibitory memories (Myers and Davis, 2002; Duvarci and Nader, 2004; Quirk and Mueller, 2008). However, we found that lactacystin injections into the NAc core prevented CPP extinction but had no effect on the formation of cocaine-induced CPP. Additionally, retrievalinduced plasticity allows new information to be integrated into the initial memory representation (Hupbach et al, 2007; Alberini, 2011). Thus, we speculated that ubiquitin-proteasome system-dependent protein degradation is involved in the integration of new information into the existing cocaine reward memory but not the formation of cocaine reward memory. However, another possibility is that the effect of lactacystin on extinction learning may be attributable to the prevention of subsequent decreases in the original memory trace. This is consistent with the notion that extinction also involves an unlearning mechanism, and the memory trace is partially erased by extinction training (Lee et al, 2008; Lai et al, 2012).

In the present study, we focused on NSF, a molecular chaperone that regulates the trafficking of protein complexes, such as the soluble NSF attachment protein receptor (Whiteheart et al, 2001) and AMPA receptor complexes (Nishimune et al, 1998; Noel et al, 1999). The experimental design was inspired by Yao et al (2008), in which PKM $\zeta$ maintained late long-term potentiation through the persistent NSF/GluR2-dependent trafficking of AMPA receptors to the synapse. PKM $\zeta$ is responsible for the maintenance of many types of memory (Pastalkova et al, 2006; Shema et al, 2007; Serrano et al, 2008), including drug-related memories (He et al, 2011; Li et al, 2011). We speculated that retrievalinduced memory destabilization may accompany the changes in NSF levels, and this may be induced by ubiquitin-proteasome system-mediated protein degradation. Indeed, we found that polyubiquitinated NSF significantly increased 15 and $60 \mathrm{~min}$ after the retrieval of cocaine reward memory, and NSF protein levels decreased 60 and $120 \mathrm{~min}$ after retrieval in the synaptic region but returned to basal levels $24 \mathrm{~h}$ later.

Another PSD protein, PSD-95, did not exhibit timedependent changes. Furthermore, in Experiments 2 and 4, NSF levels correlated with the expression of cocaineinduced CPP. Therefore, the changes in NSF levels after cocaine retrieval were specific. Additionally, our findings on GluR2 levels also supported our hypothesis about the role of NSF in cocaine reward memory. Notably, we only detected NSF protein levels in the synaptosomal membrane fraction in the present study. Further studies need to explore NSF levels in the total extract to elucidate alterations in NSF distribution after the retrieval of cocaine memory. NSF is the regulator of GluR2 (Noel et al, 1999), and the ubiquitination and degradation of NSF may affect the stability of the proteins that require NSF to maintain them in the PSD. We found that similar to NSF, GluR2 levels in the NAc core decreased when cocaine-induced CPP was disrupted by anisomycin and when cocaine-induced CPP was extinguished. These findings extend previous studies on the effects of extinction training after cocaine exposure on GluR levels in the NAc (Sutton et al, 2003; Ghasemzadeh et al, 2009) demonstrating that extinction training upregu- lated GluR1 and GluR2 levels in the NAc shell in cocaine self-administration. Considering the critical role of the endocytosis of GluR2-containing AMPA receptors in memory reconsolidation (Rao-Ruiz et al, 2011), further studies are needed to determine the alterations in the distribution of AMPA receptors in the NAc in the reconsolidation and extinction of cocaine reward memory. Additionally, all of these studies were conducted in rats that underwent cocaineinduced CPP training. Further studies are needed to determine how protein levels change in animals that are not exposed to cocaine or CPP training and how protein synthesis inhibitors and proteasome inhibitors affect protein levels in animals that are not exposed to cocaine.

\section{Concluding Remarks}

Our results revealed that ubiquitin-proteasome systemmediated protein degradation may be a potential mechanism for the destabilization phase of the reconsolidation and extinction of cocaine reward memory. The destabilization of cocaine reward memory was related to a loss of the synaptic scaffold protein NSF in the synaptosomal membrane in the NAc core. These findings suggest the possible role of protein degradation-dependent mechanisms in cocaine reward.

\section{ACKNOWLEDGEMENTS}

This work was supported in part by the Natural Science Foundation of China (nos. 31230033, 91132716, and 31070958). We thank Dr Yavin Shaham for his helpful comments on the manuscript.

\section{DISCLOSURE}

The authors declare no conflict of interest.

\section{REFERENCES}

Alberini CM (2011). The role of reconsolidation and the dynamic process of long-term memory formation and storage. Front Behav Neurosci 5: 12.

Anderson SM, Famous KR, Sadri-Vakili G, Kumaresan V, Schmidt HD, Bass CE et al (2008). CaMKII: a biochemical bridge linking accumbens dopamine and glutamate systems in cocaine seeking. Nat Neurosci 11: 344-353.

Artinian J, McGauran AM, De Jaeger X, Mouledous L, Frances B, Roullet P (2008). Protein degradation, as with protein synthesis, is required during not only long-term spatial memory consolidation but also reconsolidation. Eur J Neurosci 27: 3009-3019.

Bardo MT, Rowlett JK, Harris MJ (1995). Conditioned place preference using opiate and stimulant drugs: a meta-analysis. Neurosci Biobehav Rev 19: 39-51.

Bekinschtein P, Katche C, Slipczuk L, Gonzalez C, Dorman G, Cammarota $M$ et al (2010). Persistence of long-term memory storage: new insights into its molecular signatures in the hippocampus and related structures. Neurotox Res 18: 377-385.

Ben Mamou C, Gamache K, Nader K (2006). NMDA receptors are critical for unleashing consolidated auditory fear memories. Nat Neurosci 9: 1237-1239. 
Bernardi RE, Lattal KM, Berger SP (2007). Anisomycin disrupts a contextual memory following reactivation in a cocaine-induced locomotor activity paradigm. Behav Neurosci 121: 156-163.

Childress AR, McLellan AT, Ehrman R, O’Brien CP (1988). Classically conditioned responses in opioid and cocaine dependence: a role in relapse? NIDA Res Monogr 84: 25-43.

Conrad KL, Tseng KY, Uejima JL, Reimers JM, Heng LJ, Shaham Y et al (2008). Formation of accumbens GluR2-lacking AMPA receptors mediates incubation of cocaine craving. Nature 454: 118-121.

Cornish JL, Kalivas PW (2000). Glutamate transmission in the nucleus accumbens mediates relapse in cocaine addiction. J Neurosci 20: RC89.

Dunah AW, Standaert DG (2001). Dopamine D1 receptordependent trafficking of striatal NMDA glutamate receptors to the postsynaptic membrane. J Neurosci 21: 5546-5558.

Duvarci S, Nader K (2004). Characterization of fear memory reconsolidation. J Neurosci 24: 9269-9275.

Ehlers MD (2003). Activity level controls postsynaptic composition and signaling via the ubiquitin-proteasome system. Nat Neurosci 6: 231-242.

Eisenberg M, Kobilo T, Berman DE, Dudai Y (2003). Stability of retrieved memory: inverse correlation with trace dominance. Science 301: 1102-1104.

Famous KR, Kumaresan V, Sadri-Vakili G, Schmidt HD, Mierke DF, Cha JH et al (2008). Phosphorylation-dependent trafficking of GluR2-containing AMPA receptors in the nucleus accumbens plays a critical role in the reinstatement of cocaine seeking. J Neurosci 28: 11061-11070.

Fan HY, Cherng CG, Yang FY, Cheng LY, Tsai CJ, Lin LC et al (2010). Systemic treatment with protein synthesis inhibitors attenuates the expression of cocaine memory. Behav Brain Res 208: $522-527$.

Fioravante D, Liu RY, Byrne JH (2008). The ubiquitin-proteasome system is necessary for long-term synaptic depression in Aplysia. J Neurosci 28: 10245-10256.

Fonseca R, Vabulas RM, Hartl FU, Bonhoeffer T, Nagerl UV (2006). A balance of protein synthesis and proteasome-dependent degradation determines the maintenance of LTP. Neuron 52: 239-245.

Fuchs RA, Bell GH, Ramirez DR, Eaddy JL, Su ZI (2009). Basolateral amygdala involvement in memory reconsolidation processes that facilitate drug context-induced cocaine seeking. Eur J Neurosci 30: 889-900.

Ghasemzadeh MB, Vasudevan P, Mueller C, Seubert C, Mantsch JR (2009). Region specific alterations in glutamate receptor expression and subcellular distribution following extinction of cocaine self-administration. Brain Res 1267: 89-102.

He YY, Xue YX, Wang JS, Fang Q, Liu JF, Xue LF et al (2011). PKMzeta maintains drug reward and aversion memory in the basolateral amygdala and extinction memory in the infralimbic cortex. Neuropsychopharmacology 36: 1972-1981.

Hegde AN, Goldberg AL, Schwartz JH (1993). Regulatory subunits of cAMP-dependent protein kinases are degraded after conjugation to ubiquitin: a molecular mechanism underlying long-term synaptic plasticity. Proc Natl Acad Sci USA 90: 7436-7440.

Hupbach A, Gomez R, Hardt O, Nadel L (2007). Reconsolidation of episodic memories: a subtle reminder triggers integration of new information. Learn Mem 14: 47-53.

Ito R, Robbins TW, Everitt BJ (2004). Differential control over cocaine-seeking behavior by nucleus accumbens core and shell. Nat Neurosci 7: 389-397.

Jarome TJ, Werner CT, Kwapis JL, Helmstetter FJ (2011). Activity dependent protein degradation is critical for the formation and stability of fear memory in the amygdala. PLoS ONE 6: e24349.

Jiang YH, Armstrong D, Albrecht U, Atkins CM, Noebels JL, Eichele G et al (1998). Mutation of the Angelman ubiquitin ligase in mice causes increased cytoplasmic p53 and deficits of contextual learning and long-term potentiation. Neuron 21: 799-811.

Joels G, Lamprecht R (2010). Interaction between N-ethylmaleimide-sensitive factor and GluR2 is essential for fear memory formation in lateral amygdala. J Neurosci 30: 15981-15986.

Karpova A, Mikhaylova M, Thomas U, Knopfel T, Behnisch T (2006). Involvement of protein synthesis and degradation in long-term potentiation of Schaffer collateral CA1 synapses. J Neurosci 26: 4949-4955.

Lai CS, Franke TF, Gan WB (2012). Opposite effects of fear conditioning and extinction on dendritic spine remodelling. Nature 483: 87-91.

Lee JL (2008). Memory reconsolidation mediates the strengthening of memories by additional learning. Nat Neurosci 11: 1264-1266.

Lee JL, Milton AL, Everitt BJ (2006). Cue-induced cocaine seeking and relapse are reduced by disruption of drug memory reconsolidation. J Neurosci 26: 5881-5887.

Lee SH, Choi JH, Lee N, Lee HR, Kim JI, Yu NK et al (2008). Synaptic protein degradation underlies destabilization of retrieved fear memory. Science 319: 1253-1256.

Lee SH, Liu L, Wang YT, Sheng M (2002). Clathrin adaptor AP2 and NSF interact with overlapping sites of GluR2 and play distinct roles in AMPA receptor trafficking and hippocampal LTD. Neuron 36: 661-674.

Li FQ, Xue YX, Wang JS, Fang Q, Li YQ, Zhu WL et al (2010). Basolateral amygdala cdk5 activity mediates consolidation and reconsolidation of memories for cocaine cues. J Neurosci 30: 10351-10359.

Li YQ, Li FQ, Wang XY, Wu P, Zhao M, Xu CM et al (2008). Central amygdala extracellular signal-regulated kinase signaling pathway is critical to incubation of opiate craving. J Neurosci 28: $13248-13257$.

Li YQ, Xue YX, He YY, Li FQ, Xue LF, Xu CM et al (2011). Inhibition of PKMzeta in nucleus accumbens core abolishes long-term drug reward memory. J Neurosci 31: 5436-5446.

Lopez-Salon M, Alonso M, Vianna MR, Viola H, Mello e Souza T, Izquierdo I et al (2001). The ubiquitin-proteasome cascade is required for mammalian long-term memory formation. Eur J Neurosci 14: 1820-1826.

Lu L, Grimm JW, Hope BT, Shaham Y (2004). Incubation of cocaine craving after withdrawal: a review of preclinical data. Neuropharmacology 47(Suppl 1): 214-226.

Lu L, Hope BT, Dempsey J, Liu SY, Bossert JM, Shaham Y (2005). Central amygdala ERK signaling pathway is critical to incubation of cocaine craving. Nat Neurosci 8: 212-219.

Lu L, Wang X, Wu P, Xu C, Zhao M, Morales M et al (2009). Role of ventral tegmental area glial cell line-derived neurotrophic factor in incubation of cocaine craving. Biol Psychiatry 66: 137-145.

Mao LM, Wang W, Chu XP, Zhang GC, Liu XY, Yang YJ et al (2009). Stability of surface NMDA receptors controls synaptic and behavioral adaptations to amphetamine. Nat Neurosci 12: 602-610.

Meil WM, See RE (1996). Conditioned cued recovery of responding following prolonged withdrawal from self-administered cocaine in rats: an animal model of relapse. Behav Pharmacol 7: 754-763.

Meredith GE, Agolia R, Arts MP, Groenewegen HJ, Zahm DS (1992). Morphological differences between projection neurons of the core and shell in the nucleus accumbens of the rat. Neuroscience 50: 149-162.

Meredith GE, Baldo BA, Andrezjewski ME, Kelley AE (2008). The structural basis for mapping behavior onto the ventral striatum and its subdivisions. Brain Struct Funct 213: 17-27.

Merlo E, Romano A (2007). Long-term memory consolidation depends on proteasome activity in the crab Chasmagnathus. Neuroscience 147: 46-52. 
Milekic MH, Brown SD, Castellini C, Alberini CM (2006). Persistent disruption of an established morphine conditioned place preference. J Neurosci 26: 3010-3020.

Miller CA, Marshall JF (2005). Molecular substrates for retrieval and reconsolidation of cocaine-associated contextual memory. Neuron 47: 873-884.

Milton AL, Everitt BJ (2010). The psychological and neurochemical mechanisms of drug memory reconsolidation: implications for the treatment of addiction. Eur J Neurosci 31: 2308-2319.

Myers KM, Davis M (2002). Behavioral and neural analysis of extinction. Neuron 36: 567-584.

Nader K, Hardt O (2009). A single standard for memory: the case for reconsolidation. Nat Rev Neurosci 10: 224-234.

Nader K, Schafe GE, Le Doux JE (2000). Fear memories require protein synthesis in the amygdala for reconsolidation after retrieval. Nature 406: 722-726.

Nishimune A, Isaac JT, Molnar E, Noel J, Nash SR, Tagaya M et al (1998). NSF binding to GluR2 regulates synaptic transmission. Neuron 21: 87-97.

Noel J, Ralph GS, Pickard L, Williams J, Molnar E, Uney JB et al (1999). Surface expression of AMPA receptors in hippocampal neurons is regulated by an NSF-dependent mechanism. Neuron 23: 365-376.

O’Brien CP, Childress AR, McLellan AT, Ehrman R (1992). Classical conditioning in drug-dependent humans. Ann NY Acad Sci 654: 400-415.

Osten P, Srivastava S, Inman GJ, Vilim FS, Khatri L, Lee LM et al (1998). The AMPA receptor GluR2 C terminus can mediate a reversible, ATP-dependent interaction with NSF and alpha- and beta-SNAPs. Neuron 21: 99-110.

Pastalkova E, Serrano P, Pinkhasova D, Wallace E, Fenton AA, Sacktor TC (2006). Storage of spatial information by the maintenance mechanism of LTP. Science 313: 1141-1144.

Paxinos G, Watson C (2005). The Rat Brain in Stereotaxic Coordinates. 5th edn. Elsevier Academic Press: Amsterdam.

Pedreira ME, Maldonado H (2003). Protein synthesis subserves reconsolidation or extinction depending on reminder duration. Neuron 38: 863-869.

Quirk GJ, Mueller D (2008). Neural mechanisms of extinction learning and retrieval. Neuropsychopharmacology 33: 56-72.

Ramirez DR, Bell GH, Lasseter HC, Xie X, Traina SA, Fuchs RA (2009). Dorsal hippocampal regulation of memory reconsolidation processes that facilitate drug context-induced cocaineseeking behavior in rats. Eur J Neurosci 30: 901-912.

Rao-Ruiz P, Rotaru DC, van der Loo RJ, Mansvelder HD, Stiedl O, Smit $\mathrm{AB}$ et al (2011). Retrieval-specific endocytosis of GluA2-
AMPARs underlies adaptive reconsolidation of contextual fear. Nat Neurosci 14: 1302-1308.

Rosenblum K, Meiri N, Dudai Y (1993). Taste memory: the role of protein synthesis in gustatory cortex. Behav Neural Biol 59: 49-56.

Schiller D, Monfils MH, Raio CM, Johnson DC, Ledoux JE, Phelps EA (2010). Preventing the return of fear in humans using reconsolidation update mechanisms. Nature 463: 49-53.

Serrano P, Friedman EL, Kenney J, Taubenfeld SM, Zimmerman JM, Hanna J et al (2008). PKMzeta maintains spatial, instrumental, and classically conditioned long-term memories. PLoS Biol 6: 2698-2706.

Shema R, Sacktor TC, Dudai Y (2007). Rapid erasure of long-term memory associations in the cortex by an inhibitor of PKM zeta. Science 317: 951-953.

Song I, Kamboj S, Xia J, Dong H, Liao D, Huganir RL (1998). Interaction of the N-ethylmaleimide-sensitive factor with AMPA receptors. Neuron 21: 393-400.

Sutton MA, Schmidt EF, Choi KH, Schad CA, Whisler K, Simmons $\mathrm{D}$ et al (2003). Extinction-induced upregulation in AMPA receptors reduces cocaine-seeking behaviour. Nature 421: 70-75.

Suzuki A, Josselyn SA, Frankland PW, Masushige S, Silva AJ, Kida S (2004). Memory reconsolidation and extinction have distinct temporal and biochemical signatures. J Neurosci 24: 4787-4795.

Theberge FR, Milton AL, Belin D, Lee JL, Everitt BJ (2010). The basolateral amygdala and nucleus accumbens core mediate dissociable aspects of drug memory reconsolidation. Learn Mem 17: 444-453.

Tronson NC, Taylor JR (2007). Molecular mechanisms of memory reconsolidation. Nat Rev Neurosci 8: 262-275.

Whiteheart SW, Schraw T, Matveeva EA (2001). N-ethylmaleimide sensitive factor (NSF) structure and function. Int Rev Cytol 207: 71-112.

Xu CM, Wang J, Wu P, Zhu WL, Li QQ, Xue YX et al (2009). Glycogen synthase kinase 3beta in the nucleus accumbens core mediates cocaine-induced behavioral sensitization. J Neurochem 111: 1357-1368.

Yao Y, Kelly MT, Sajikumar S, Serrano P, Tian D, Bergold PJ et al (2008). PKM zeta maintains late long-term potentiation by N-ethylmaleimide-sensitive factor/GluR2-dependent trafficking of postsynaptic AMPA receptors. J Neurosci 28: 7820-7827.

Yi JJ, Ehlers MD (2005). Ubiquitin and protein turnover in synapse function. Neuron 47: 629-632.

Yu LL, Wang XY, Zhao M, Liu Y, Li YQ, Li FQ et al (2009). Effects of cannabinoid CB1 receptor antagonist rimonabant in consolidation and reconsolidation of methamphetamine reward memory in mice. Psychopharmacology (Berl) 204: 203-211. 